\title{
Grading the Graded Care Profile
}

Robin Sen (University of Sheffield) and Dr Pam Green Lister (Glasgow School of Social Work)

April 17 $7^{\text {th }}, 2012$ 


\section{Acknowledgements}

$\square$ Funded by BASPCAN

$\square$ Joint evaluation work with Glasgow City Council 


\section{GCP as response to neglect}

- Difficulties in professional identification and response to neglect

- Co-existence with other difficulties

- Assessment of parenting is not value free

- GCP 'Objective' measure of caring using qualitative bipolar five point scale

- Breaks caring task down using into specific 'sub-areas' and 'items' of care

- Previous claims

- Reliability

- User-friendly for both professionals and parents

- Quick to undertake 


\section{Data}

- Baseline data gathered by local authority from practitioners: Questionnaires (22), follow up interviews (8)

- Two focus groups with practitioners who had used the GCP

- Individual contact with practitioners who had or were due to use the tool (56)

- Semi-structured interviews with parents who had previously had the GCP used with them (4) and with practitioners managing these cases (4)

1 4 Observations of how the GCP was being used with 3 sets of parents

- Brief follow up interviews with parents (2) and practitioners (2) practitioners where practitioners were observed using the GCP 
GCP as an assessment tool

\begin{tabular}{|c|c|c|c|}
\hline Practitioner Views of GCP & Good & Acceptable & Poor \\
\hline $\begin{array}{l}\text { Use in assessing neglect } \\
\text { (20 responses) }\end{array}$ & $\begin{array}{l}82 \% \\
(18 / 20)\end{array}$ & $\begin{array}{l}9 \% \\
(2 / 20)\end{array}$ & $\begin{array}{l}0 \% \\
(0 / 20)\end{array}$ \\
\hline $\begin{array}{l}\text { Tool for assisting multi- } \\
\text { professional assessment } \\
\text { ( } 18 \text { responses) }\end{array}$ & $\begin{array}{l}59 \% \\
(13 / 18)\end{array}$ & $\begin{array}{l}23 \% \\
(5 / 18)\end{array}$ & $\begin{array}{l}0 \% \\
(0 / 18)\end{array}$ \\
\hline $\begin{array}{l}\text { GCP as tool for engaging } \\
\text { parents } \\
\text { (2I responses) }\end{array}$ & $\begin{array}{l}45 \% \\
(10 / 21)\end{array}$ & $\begin{array}{l}32 \% \\
(7 / 21)\end{array}$ & $\begin{array}{l}18 \% \\
(4 / 21)\end{array}$ \\
\hline
\end{tabular}


- Interviewer: Did you feel that the Graded Care Profile gave an accurate view of your parenting?

- Mother: Oh God, aye, aye, I'm glad that I had something like this. (Case 3)

- It showed me where I was going wrong and how I could build myself up. It makes you see different things. (Mother, case 5) 


\section{But questions about its accuracy}

- Minority view, but clear theme, amongst practitioners statements about the tool:

- "very, very subjective" (Practitioner Interview)

- I am not convinced that it is hugely accurate ( ) each of the items, the choices that they give you, they are pretty specific, so there isn't a huge amount of leeway, but there is some leeway, I suppose, in the interpretation of you going through that (SW, Case Four)

- Some concerns about accuracy where reliant on parents' selfreporting 


\section{Parental Engagement}

- Language in the GCP a barrier to parental engagement

- But two of seven parents very positive experiences of its use

- Case Five: Parent very favourable experience of use of the GCP, supported by observation data

- Relationship SW and mother - tool use to generate dialogue

- Second time of use and progress in between times

- SW in all but one items agreed with parents' score or suggested a better (lower) score 


\section{Where there was disagreement, scoring of the GCP could exacerbate it}

Parent Case Four

$>$ he's ((the social worker)) not here twenty four - seven so he doesn't see it all does he?

$>$ I'd have scored myself a two because I feel aye fair enough it isnae Prada and all that but it's like Nike, Adidas and Lacosse, any trainers we've got is Lacosse trainers. 30 to 40 pound a pair of trainers and Greg's ((the social worker)) saying he thinks I'm not doing my best at. Everyone's like that, what you talking about?

SW Case Four

- She was really up for doing it [the GCP]... I think she enjoyed doing it. 


\section{Observation, case six}

- F: The only reason l'm early for my ((Addictions)) appointment and all is because I take the weans to school and then I just=

- HV: =so maybe I should get you, may be I should get you (for) appointments at quarter to nine in the morning in my office=

1 $\mathrm{F}:$ =nae bother $(\mathrm{)}=$

- HV: =but I doubt you'll make it though, I doubt you will make it though

D: I would, nine o'clock

- HV: I think we are taking bets on that one

, F: Nine o'clock 


\section{Going forward with the GCP}

- Study illustrated some strengths to the GCP : breaking caring task down, allowing discussion about standards of care in some cases

- Need to modify language (academic, abstract)

- Does it give an objective assessment of care?

- Diagnostic/prescriptive use to grade care appears in tension with dialogical use to encourage discussion around care standards 